Rajmund TRZEBIATOWSKI, Jolanta GAJ

Fish biology

\title{
GROWTH, FEEDING AND ECONOMIC IMPORT ANCE OF SMELT (OSMERUS EPERLANUS L.) IN THE LAKE MIEDWIE
}

\section{WZROST, ODŻYWIANIE SIĘ I ZNACZENIE GOSPODARCZE STYNKI (OSMERUS EPERLANUS L.) Z JEZIORA MIEDWIE}

Institute of Aquaculture and Fisheries Technology

The paper discusses growth, feeding, and economic importance of smelt (Osmerus eperlanus L.) in the Lake Miedwie. The growth rate was back-calculated from otoliths using the Dahl-Lea method. When studying smelt feeding, both qualitative and quantitative aspects of food composition were taken into account as well as frequency of occurrence of each component. Additionally, the Lake Miedwie smelt's growth rate and feeding were compared to those features exhibited by the species in other water bodies.

\section{INTRODUCTION}

Smelt (Osmerus eperlanus L.) is a pelagic species inhabiting lagoons and lakes in the northern part of Poland. Those fishes do not attain any considerable size hence their limited commercial importance. However, due to the species' significant biological features, its economic function in our waters proves important. Inhabitants of the pelagic zone, smelt take advantage of abundant resources of crustacean zooplankton, not frequently consumed by other representatives of our ichthyofauna. At the same time, smelt make a significant contribution to the food of predatory species, mainly pikeperch. 
Smelt do not occur commonly in the Polish waters. On account, however, of the species' biological value, there are suggestions to promote its occurrence (Bernatowicz, 1968). Owing to that reason mainly, there arises a need to gain a closer insight into the species' biology, growth and feeding habits at the first place, the knowledge of which can be practically utilised in stocking other water bodies with smelt.

\section{MATERIALS AND METHODS}

The materials studied were obtained from commercial catches carried out in the lake in winter-spring 1976/1977 with a pair pelagic trawl.

Fishes to be examined were selected at random. Each individual was measured and its scales, otoliths and gut taken out. The fish age and annual increments were read from otoliths in the incident light of a microscope. Digestive tracts collected were fixed in $4 \%$ formalin, their contents being subsoquently analysed under a binocular microscope using a plankton dish (Starmach, 1955). The food composition was studied quantitatively as well as qualitatively, the frequency of occurrence of its components being determined too. The qualitative analysis was based on the key for freshwater fauna identification (Rybak, 1971). In the quantitative studies, gut contents were analysed using standard weights given for various organisms by Starmach (2955) and Morduchaj-Boltovskij(1954). Fishes found in smelt's food were determined from scales and bones.

Table 1

Presentation of the material collected

\begin{tabular}{|l|c|c|c|c|}
\hline \multicolumn{1}{|c|}{$\begin{array}{c}\text { Date of } \\
\text { sampling }\end{array}$} & $\begin{array}{c}\text { Number of } \\
\text { fishes }\end{array}$ & $\begin{array}{c}\text { Mean length } \\
(\mathrm{cm})\end{array}$ & $\begin{array}{c}\text { Length range } \\
(\mathrm{cm})\end{array}$ & $\begin{array}{c}\text { Weight range } \\
(\mathrm{g})\end{array}$ \\
\hline December 19, 1976 & 248 & 9.98 & $\begin{array}{l}6.5-22.0 \\
6.5-13.8\end{array}$ & $\begin{array}{l}1.390-67.840 \\
1.123-15.450\end{array}$ \\
\hline March 23, 1977 & 255 & 9.18 & $6.5-22.0$ & $1.123-67.840$ \\
\hline Total & 503 & 9.58 & 6 \\
\hline
\end{tabular}

The otolith radius-body length relationship was established for smelt from correlation coefficient and regression line. The growth rate was back-calculated using the uncorrected Dahl-Lea method.

The Lake Miedwie catches of smelt and other species were summarised from commercial statistics available. 


\section{RESULTS OF STUDIES}

Percentage share of smelt in catches

The Lake Miedwie ichthyofauna is very rich in species, no one of which occupies an economically leading position. At present, the catches consist mainly of species belonging to a less valuable group (roach, bream, perch, smelt), whereas valuable predators (eel, pikeperch, pike) are caught to a lower degree. Those species that are of a considerable value (ablen and lavaret) make up as little as $1.04 \%$ of catches in the lake (Fig. 1). The situation as described can be accounted for by an increasing eutrophication of the lake, which tend to deteriorate the habitat otherwise fit for ablen and lavaret.

Smelt is one of the most abundant fish species in the lake. The catches have been sig vicantly increased in recent years: from 5.3\% of the total catch in 1970-1973 to 8. ' in 1974-1977. During that period a pelagic pair trawl has been introduced along with echosounding operations used to localise smelt schools. The pair trawl has contributed to the increase in catches and allowed to prolong fishing operations to encompass winter months as well. Until that, the winter smelt fishery employing, for instance, drag-nets, was rendered impossible by very strong winds and therefore smelt was fished for in spring only. Presently, the fishing operations extend from October through March with a peak in January-February when the species forms compact spawning aggregations.

The intensified fishery did not, however, caused any apparent decrease in abundance of the Lake Miedwie smelt. It is supposed that the mass occurrence of the species disturbes the biological equilibrium in the Lake Miedwie ichthyofauna by impairing conditions for living and growth of those species that present a greater economic importance.

\section{LENGTH AND AGE OF SMELT}

The material studied contained length classes covering the range of $6.5-22.0 \mathrm{~cm}$; the $10.0,10.5,9.5$ and $7.0 \mathrm{~cm}$ groups being represented most abundantly; some of the classes in the range were missing (Table 2). As seen from Table 2, the Lake Miedwie smelt catches are dominated by small individuals. Large ones reaching 22.0 and even $28.5 \mathrm{~cm}$ are being found as well (Cywiński, 1974).

The age of fishes examined ranged from $0+$ to $5+$ (Table 3 ), the age groups $2+, 1+$, and $0+$ being found most frequently which means that young individuals constituted the majority of examined fishes. Older ones $(3+, 4+$, and $5+)$ did not occur in any substantial amounts, they made up $10.4 \%$ of the material examined, the $4+$ and $5+$ groups amounting to as little as $1.8 \%$ (Table 3 ). The predomination of young individuals is typical of most smelt populations, as shown by Lillelund (1961), Belyanina (1969), Rembiszewski (1970), and Fedorova (1973). 


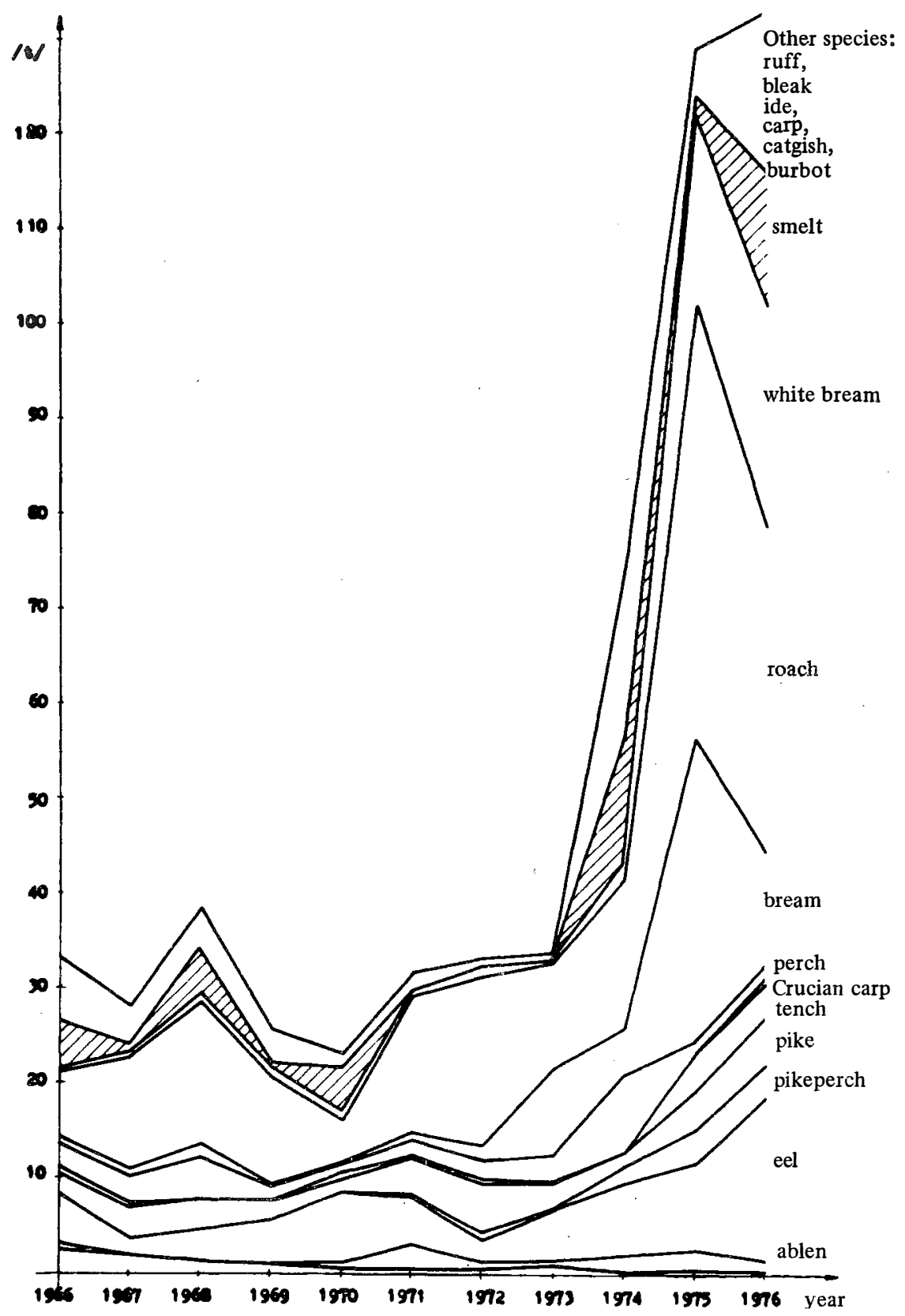

Fig. 1. Catches from the Lake Miedwie over 1966-1977 
Table 2

Fish length distribution

\begin{tabular}{|c|c|c|c|c|c|c|c|c|}
\hline \multirow{2}{*}{$\begin{array}{c}\text { Length } \\
\text { class } \\
(\mathrm{cm})\end{array}$} & \multicolumn{2}{|c|}{$\begin{array}{l}\text { No of fish } \\
\text { per class }\end{array}$} & \multirow{2}{*}{$\begin{array}{l}\text { Length } \\
\text { class } \\
(\mathrm{cm})\end{array}$} & \multicolumn{2}{|c|}{$\begin{array}{l}\text { No of fish } \\
\text { per class }\end{array}$} & \multirow{2}{*}{$\begin{array}{l}\text { Length } \\
\text { class } \\
(\mathrm{cm})\end{array}$} & \multicolumn{2}{|c|}{$\begin{array}{c}\text { No of fish } \\
\text { per class }\end{array}$} \\
\hline & ind. & $\%$ & & ind. & $\%$ & & ind. & $\%$ \\
\hline 6.5 & 7 & 1.4 & 10.0 & 126 & 25.0 & 15.0 & 1 & 0.2 \\
\hline 7.0 & 55 & 10.9 & 10.5 & 89 & 17.7 & 16.0 & 1 & 0.2 \\
\hline 7.5 & 41 & 8.2 & 11.0 & 44 & 8.7 & 17.0 & 1 & 0.2 \\
\hline 8.0 & 11 & 2.2 & 11.5 & 18 & 3.6 & 17.5 & 2 & 0.4 \\
\hline 8.5 & 3 & 0.6 & 12.0 & 7 & 1.4 & 18.5 & 1 & 0.2 \\
\hline 9.0 & 13 & 2.6 & 12.5 & 1 & 0.2 & 19.5 & 1 & 0.2 \\
\hline 9.5 & 79 & 15.7 & 13.5 & 1 & 0.2 & 22.0 & 1 & 0.2 \\
\hline Total & & & $\begin{array}{l}\text { No. of clas- } \\
\text { ses: } 21\end{array}$ & & $\begin{array}{l}\text { No. of } \\
\text { fishes: } 503\end{array}$ & & & $\begin{array}{l}\text { Per cent } \\
100\end{array}$ \\
\hline
\end{tabular}

Table 3

Age composition of fishes examined

\begin{tabular}{|c|c|c|c|}
\hline \multirow{2}{*}{ Age group } & \multicolumn{2}{|c|}{ No of fish per group } & $\begin{array}{c}\text { Length range } \\
\text { (from direct measurements) } \\
\text { (cm) }\end{array}$ \\
\cline { 2 - 4 } & ind. & $\%$ & $6.5-8.8$ \\
$0+$ & 102 & 20.4 & $7.2-10.9$ \\
$1+$ & 113 & 22.5 & $9.3-11.7$ \\
$2+$ & 232 & 46.3 & $10.4-12.3$ \\
$3+$ & 45 & 9.0 & $13.8-18.6$ \\
$4+$ & 7 & 1.4 & $19.5-22.0$ \\
$5+$ & 2 & 0.4 & $6.5-22.0$ \\
\hline Total & 501 & 100.0 & \\
\hline
\end{tabular}

\section{OTOLITH RADIUS-BODY LENGTH RELATIONSHIP}

The correlation coefficient and regression line calculated from statistical formulae given by Szydłowski et al.(1974) were used to determine the relationship. The correlation coefficient was found to be

$$
q=0.9557
$$

and the regression equation

$$
y=0.1123+0.149
$$

Fig. 2 illustrates the regression line course. The y-axis intercept is at a small distance from the origin; therefore the otolith radius can be considered directly proportional to 


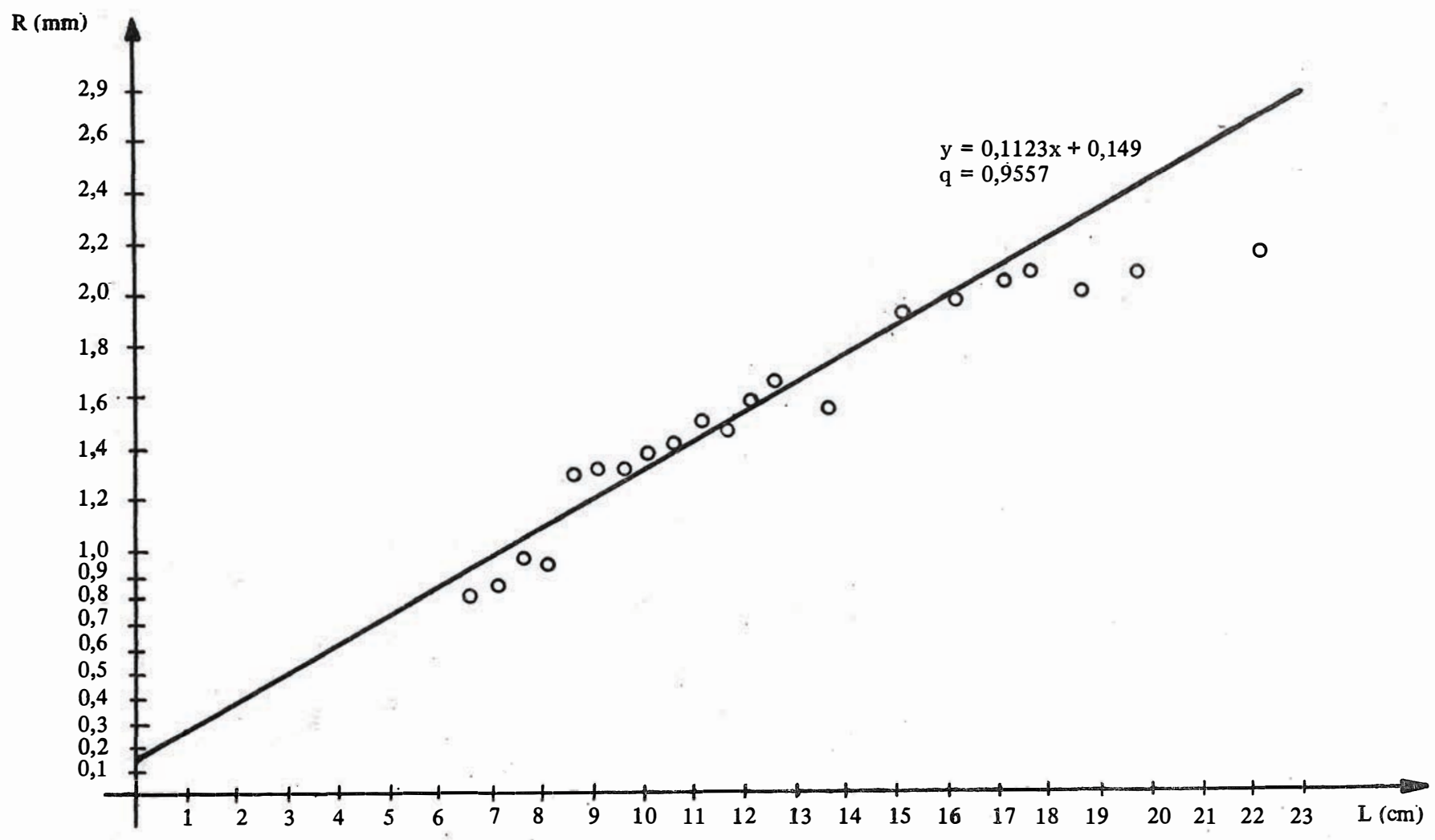

Fig. 2. Regression line 
the smelt body length. A correction factor $c$, due to its low value, was omitted in fish length back-calculations.

\section{GROWTH RATE}

Growth and length increments of the Lake Miedwie smelt, back-calculated from otoliths with the aid of the Dahl-Lea method are presented in Table 5. The highest growth rate is observed in the first year of life. In the subsequent two years (2 and 3$)$ significant decrease in growth rate is observed, another considerable increase being note in older ( 4 and 5 years) individuals. This relatively low growth rate of two- and three-year-old smelt is indicative of unfavourable feeding conditions prevailing in the lake. It can also be attributed to the intraspecific competition for food resulting from a large density of young fishes in the population with $2+$ and $1+$ individuals predominating in the catches. Similar situation was found by Lillelund (1961) who studied the smelt growth rate in the river Elbe. The high growth rate observed in older smelt $(4+$ and $5+)$ results presumably from their low densities (ca 2\% of catches) whereby the fishes enjoy better feeding conditions. Moreoever, the feeding habits of those smelt alter as the fishes switch to predation. It should be noted, however, that some individuals exhibited a high growth rate as early as in their first year of life.

Length-weight relationship

The following formula served to calculate the length"weight relationship for smelt:

$$
W=k L^{n}
$$

where:

$$
\begin{array}{ll}
\mathrm{W} & =\text { total fish weight, } \\
\mathrm{L} & =\text { total fish length }(1, \mathrm{t} .) \\
\mathrm{k} \text { and } \mathrm{n} & =\text { coefficients. }
\end{array}
$$

The coefficients $\mathrm{k}$ and $\mathrm{n}$ as calculated using the least squares method were found to amount to 0.00137 and 3.5399 , respectively. Therefore the formula takes on a form of

$$
\mathbb{W}=0.00137 \mathrm{~L}^{3.5399}
$$

A theoretical weight, calculated for smelt length classes using the above formula is presented in Fig. 3. Results of direct measurements are also presented in the picture. The graph shows weight increments to increase with fish length; the line, curving gently at the first stage, rises abruptly afterwards.

\section{Feeding}

The Lake Miedwie smelt food composition was studied on 180 guts. As pointed out by many authors (Murawska, 1968; Belyanina, 1969; Almuchov and Erostova, 1974), spawning smelt feeds very poorly if ever. Therefore stomachs collected in spring (March) usually contained digested food remains ( $40 \%$ of guts analysed) or were entirely empty (18\%), which shows the Lake Miedwie smelt to restrict their feeding during spawning. 
Growth of smelt in various water bodies $(\mathrm{cm})$

Table 4

\begin{tabular}{|c|c|c|c|c|c|c|c|c|c|c|c|c|}
\hline $\begin{array}{l}\text { Water } \\
\text { body }\end{array}$ & 1 & 2 & 3 & 4 & 5 & 6 & 7 & 8 & 9 & 10 & 11 & 12 \\
\hline $\begin{array}{l}\text { Lake Pyhäjarvi } \\
\text { (Nordquist, 1970) }\end{array}$ & 7.8 & 9.2 & 11.2 & & & & & & & & & \\
\hline $\begin{array}{l}\text { Rivers Ouse and Ne- } \\
\text { ne (Masterman, } \\
\text { 1913) }\end{array}$ & 11.4 & 17.4 & 19.2 & & & & & & & & & \\
\hline $\begin{array}{l}\text { Lake Dadej } \\
\text { (Willer, 1926) }\end{array}$ & 7.1 & 10.7 & 12.2 & 13.7 & & & & & & & & \\
\hline $\begin{array}{l}\text { Kuronski Zaliv } \\
\text { (Marre, 1931) }\end{array}$ & & & & & & & & & & & & \\
\hline $\begin{array}{l}\text { Migratory smelt } \\
\text { Non-migratory }\end{array}$ & 6.3 & 10.5 & & & & & & & & & & \\
\hline $\begin{array}{l}\text { smelt } \\
\text { River Elbe } \\
\text { (Lillelund, 1961) }\end{array}$ & 7.1 & 13.4 & $\begin{array}{l}16.1 \\
17.3\end{array}$ & $\begin{array}{l}20.4 \\
21.2\end{array}$ & 23.8 & & & & & & & \\
\hline $\begin{array}{l}\text { Lake Wigry } \\
\text { (Leskien, 1942) }\end{array}$ & 9.3 & 11.1 & 12.45 & & & & & & & & & \\
\hline $\begin{array}{l}\text { Lake Michigan } \\
\text { (Creaser, 1922) }\end{array}$ & 9.2 & 15.7 & 17.1 & & & & & & & & & \\
\hline $\begin{array}{l}\text { White Lake } \\
\text { (Fedorova, 1953) }\end{array}$ & 6.0 & 8.5 & 11.0 & & & & & & & & & \\
\hline $\begin{array}{l}\text { Lake Ilmen } \\
\text { (Fedorova, 1973) }\end{array}$ & 5.78 & 7.92 & 10.45 & & & & & & & & & \\
\hline $\begin{array}{l}\text { Lake Ladoga } \\
\text { (Arkhipceva, 1956) }\end{array}$ & 8.0 & 9.5 & 10.7 & 15.8 & 18.3 & & & & & & & \\
\hline $\begin{array}{l}\text { Lake Onega } \\
(\text { Stefanovska, 1957) }\end{array}$ & 6.3 & 8.8 & 9.4 & 10.6 & 11.0 & 11.3 & 11.8 & 12.3 & & & & \\
\hline $\begin{array}{l}\text { Lake Mjфsen } \\
\text { (Huitfeldt, 1917) }\end{array}$ & 5.3 & 8.6 & 11.7 & 14.9 & 17.8 & 19.9 & 21.8 & 23.2 & & & & \\
\hline $\begin{array}{l}\text { River Yenisey } \\
\text { (Tyurin, 1924) }\end{array}$ & 4.6 & 9.8 & 14.1 & 17.6 & 20.3 & 22.3 & 23.9 & 24.4 & 25.5 & & & \\
\hline $\begin{array}{l}\text { River Lena } \\
\text { (Pirojnikov, 1950) }\end{array}$ & - & - & - & - & - & - & 19.6 & 23.3 & 26.3 & 27.6 & 28.8 & 30.1 \\
\hline $\begin{array}{l}\text { River Neva } \\
\text { (Podarujeva, 1972) }\end{array}$ & - & 12.0 & 14.5 & 16.2 & 17.4 & 18.5 & 20.0 & 22.3 & & & & \\
\hline $\begin{array}{l}\text { White Sea --Dvina } \\
\text { Bay (Kirpičnikov, } \\
\text { 1935) }\end{array}$ & 4.1 & 9.3 & 13.2 & 16.9 & 19.1 & 21.5 & 24.6 & 27.8 & 28.1 & & & \\
\hline $\begin{array}{l}\text { Gulf of Finland } \\
\text { (Podarujeva, 1972) }\end{array}$ & -. & 11.6 & 14.1 & 16.0 & 17.4 & 18.6 & 19.9 & & & & & \\
\hline $\begin{array}{l}\text { Lake Serwy } \\
\text { (Natkański, 1935) }\end{array}$ & 6.9 & 9.1 & 11.3 & 15.0 & & & & & & & & \\
\hline $\begin{array}{l}\text { Lake Wigry } \\
\text { (Natkański, 1935) }\end{array}$ & 7.4 & 10.3 & 11.3 & 12.8 & $15: 7$ & & & & & & & \\
\hline $\begin{array}{l}\text { Lake Sajno } \\
\text { (Koszutowski,1930) }\end{array}$ & - & 11.6 & 14.3 & & & & & & & & & \\
\hline $\begin{array}{l}\text { Lake Szurpiły } \\
\text { (Koszutowski, 1930) }\end{array}$ & 8.3 & 10.5 & 12.3 & & & & & & & & & \\
\hline $\begin{array}{l}\text { Szczecin Lagoon } \\
\text { (Krzykawska, 1970) }\end{array}$ & & 7.2 & 8.0 & 11.9 & 12.5 & 13.5 & & & & & & \\
\hline $\begin{array}{l}\text { Vistula Lagoon } \\
\text { (Wiôrek, 1968) }\end{array}$ & 5.8 & 8.6 & 11.5 & 14.2 & 16.7 & 18.9 & 20.9 & & & & & \\
\hline $\begin{array}{l}\text { Lake Miedwie } \\
\text { (Rembiszewski, } \\
\text { 1970) }\end{array}$ & 7.1 & 8.7 & 14.3 & 17.2 & 19.45 & 21.1 & 22.39 & & & & & \\
\hline
\end{tabular}


The Lake Medwie smelt growth rate

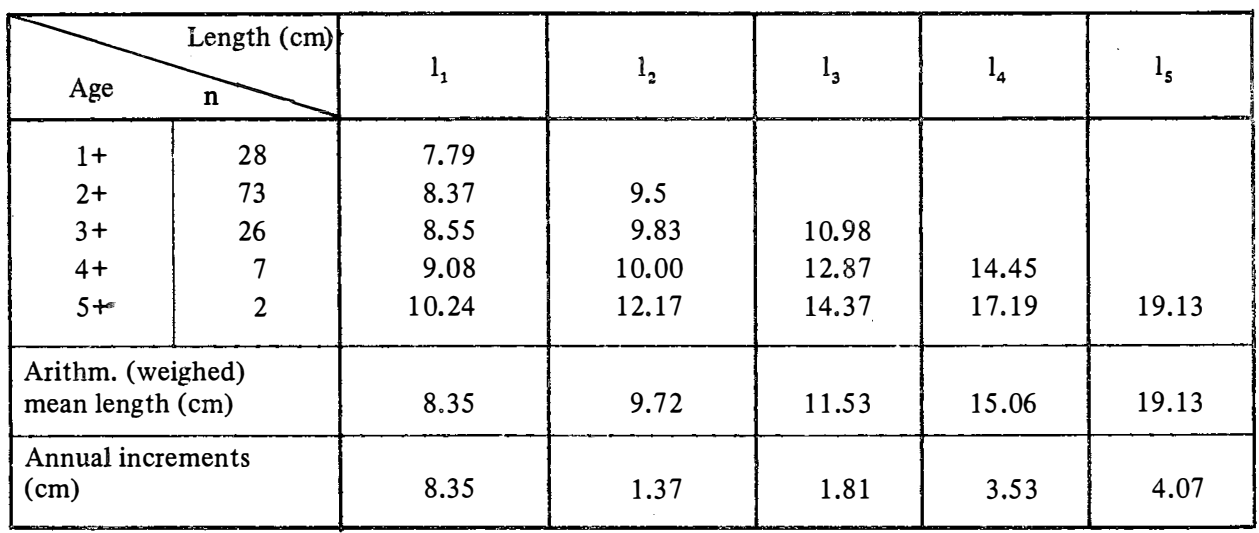

The following organisms were found to make up the Lake Miedwie smelt food in winter/spring:

Copepoda: Mesocyclops sp.

Cyclops sp.

Cladocera: Bosmina coregoni crassicornis

Alona quadrangularis

Daphnia cucullata

Insecta: larvae and pupae of Tendipedidae

Pisces: juvenile Osmerus eperlanus (L.)

Other organisms such as rotifers and mollusc veligers occurred sporadically.

Copepods (Cyclops sp. in particular) were most frequently found in smelt food (96.6\%, Table 6). Smaller was the role of cladocerans, their frequency of occurrence being $61 \%$. The analysed guts fairly often $(39 \%)$ contained tendipedid larvae and pupae. According to Gąsowska (1962) and Wiktor (1964), tendipedids are not a permanent component of smelt food; they are taken up at times when they are present in the lake and therefore available to fish.

The fishes occur in smelt food studied with a frequency of $10 \%$ which primarily results from a low number of older smelt in the material examined. It is known that fish are fed on by smelt older than two years (Koszutowski, 1930; Wiktor, 1964; Belyanina, 1969; and others).

In terms of abundance, zooplankters (copepods and cladocerans) prevail in smelt food contributing $99.3 \%$ of it. The remaining $0.7 \%$ consists of Tendipedidae, Pisces, and other items (Table 7).

The technique for assessing the importance of each food item for smelt feeding, based on determining any item's frequency and abundance in the food is not perfect. It tends to overemphasise the role of numerous albeit very small organisms, the role of larger ones 


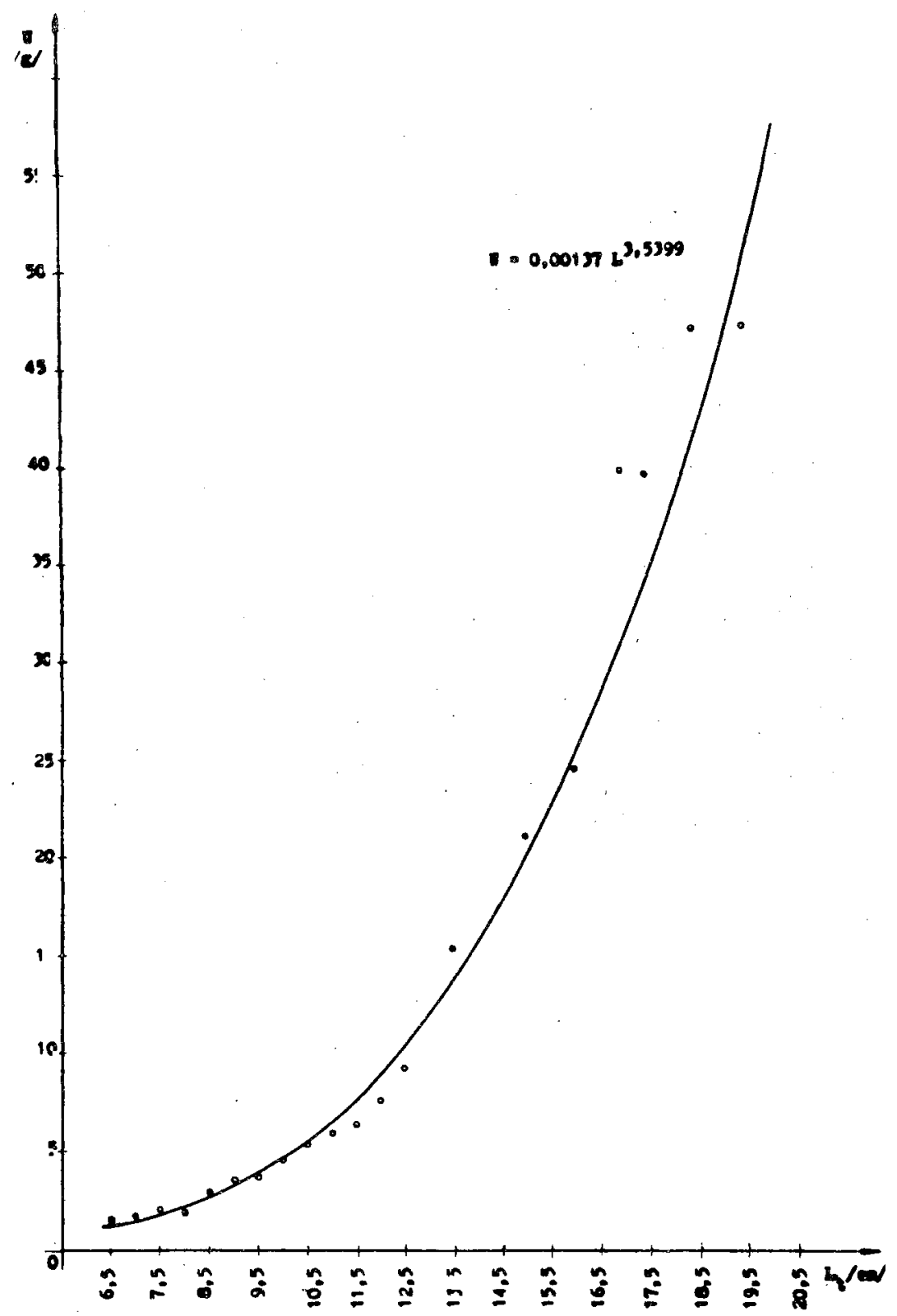

Fig. 3. Length $\left(\mathrm{L}_{\mathrm{t}}\right)$ - weight $(\mathrm{W})$ relationship for the Lake Miedwie smelt 
Table 6

Distribution of food items in the Lake Miedwie smelt food

\begin{tabular}{|l|c|r|}
\hline \multicolumn{1}{|c|}{ Food component } & $\begin{array}{r}\text { No. of digestive tracts } \\
\text { containing a given item }\end{array}$ & Per cent \\
\hline Copepoda: & 174 & 96.6 \\
Mesocyclops sp. & 75 & 41.6 \\
Cyclops sp. & 174 & 96,6 \\
Cladocera: & 110 & 61.1 \\
Bosmina coregoni crassicornis & 62 & 34.4 \\
Alona quadrangularis & 64 & 35.5 \\
Daphnia cucullata & 12 & 6.6 \\
Tendipedidae: & 71 & 39.4 \\
Pisces & 18 & 10.0 \\
Other & 16 & 8.8 \\
\hline
\end{tabular}

Table 7

Abundance of respective food items in The Lake Miedwie smelt food

\begin{tabular}{|l|r|r|}
\hline \multicolumn{1}{|c|}{ Food item } & $\begin{array}{r}\text { Abundance of food } \\
\text { componend (ind.) }\end{array}$ & Per cent \\
\hline Copepoda: & 42.631 & 97.77 \\
Mesocyclops sp. & 596 & 96.37 \\
Cyclops sp. & 42.025 & 1.55 \\
Cladocera: & 676 & 0.85 \\
Bosmina coregoni crassicornis & 370 & 0.54 \\
Alona quadrangulata & 236 & 0.16 \\
Daphnia cucullata & 70 & 0.46 \\
Tendipedidae: & 200 & 0.05 \\
Pisces & 20 & 0.17 \\
Other & 74 & 100.00 \\
\hline
\end{tabular}

being thus underestimated. Therefore, in order to work out a picture of actual quantitative relations between the food components, their respective weight percentages should be determined. The latter approach involves a determination of weights of particular organisms and expressing the data as a percentage of the total food weight. In terms of weight, then, fish appear to be the most important components of smelt food (93.1\%); they are followed by copepods $(4.8 \%)$ and insect larvae (1.7\%). Cladocerans played a very minor role indeed contributing $0.4 \%$ only (Table 8 ). 
Table 8

Weight composition of the Lake Miedwie smelt food

\begin{tabular}{|l|c|c|c|c|}
\hline \multicolumn{1}{|c|}{ lood item } & $\begin{array}{c}\text { Standard weight } \\
\text { of l ind. (mg) }\end{array}$ & $\begin{array}{c}\text { No. of } \\
\text { individuals }\end{array}$ & $\begin{array}{c}\text { Weight } \\
(\mathrm{mg})\end{array}$ & Per cent \\
\hline Copepoda: & & 42.621 & 923.025 & 4.84 \\
Mesocylops sp. & 0.350 & 596 & 208.6 & 1.09 \\
Cyclops sp. & 0.017 & 42.025 & 714.425 & 3.75 \\
Cladocera: & & & & \\
Bosmina coregoni crassicornis & 0.100 & 370 & 37.000 & 0.19 \\
Alona quadrangulata & 0.0312 & 236 & 7.363 & 0.04 \\
Daphnia cucullata & 0.330 & 70 & 23.100 & 0.12 \\
Tendipedidae: & & 200 & 314.3 & 1.65 \\
larrae & 0.1 & 100 & 10.000 & 0.05 \\
& 0.7 & 89 & 62.300 & 0.33 \\
pupae & 22.0 & 11 & 242.000 & 1.27 \\
Pisces: & & 20 & 17.746 .000 & 93.16 \\
& 0.404 & 12 & 4.948 .0 & 25.45 \\
& 1.295 & 5 & 6.475 .0 & 33.99 \\
& 2.644 & 3 & 6.423 .0 & 33.72 \\
\hline Total & & & & \\
\hline
\end{tabular}

\section{SMELT FOOD COMPOSITION AS RELATED TO FISH LENGTH}

Smelt is basically a plankton-feeder; however, a shift towards a fish food is observed with increasing growth and weight. The studies presented show the Lake Miedwie smelt to rely exclusively on zooplankton, copepods and cladocerans in the first place, during the initial period of life. The zooplankters' contribution decreases with fish growth, smaller organisms (e.g., Bosmina sp.) being at the same time replaced by larger ones (e.g., Mesocyclops sp.) (Table 9). Larger smelt $(14-20 \mathrm{~cm}$ ) ceased their feeding on plankton and switched over to fish, the latter appearing in food of individuals as small as $9.7 \mathrm{~cm}$. The fishes found in food are exclusively juvenile Osmerus eperlanus.

\section{DISCUSSION}

Smelt occurring in river mouths, in inshore sea waters, hence in waters of a certain level of salinity, as a rule exhibit a better growth rate than the freshwater-dwelling representatives of the species (Korycki, 1953; Gąsowska, 1962). When the growth rate of 
Table 9

Differences in the Lake Miedwie fish food, relative fish age

\begin{tabular}{|c|c|c|c|c|c|c|c|c|c|c|c|c|c|c|c|c|c|}
\hline \multirow{2}{*}{$\operatorname{Agc}$} & \multirow{2}{*}{$\mathrm{n}$} & \multicolumn{2}{|c|}{ Cyclops sp. } & \multicolumn{2}{|c|}{$\begin{array}{l}\text { Mesocy- } \\
\text { clops sp. }\end{array}$} & \multicolumn{2}{|c|}{$\begin{array}{l}\text { Bosmina } \\
\text { coregoni } \\
\text { crassicor. }\end{array}$} & \multicolumn{2}{|c|}{$\begin{array}{c}\text { Alona } \\
\text { quadran. }\end{array}$} & \multicolumn{2}{|c|}{$\begin{array}{l}\text { Daphnia } \\
\text { cucullata }\end{array}$} & \multicolumn{2}{|c|}{$\begin{array}{l}\text { Tendipedi- } \\
\text { dae }\end{array}$} & \multicolumn{2}{|c|}{ Pisces } & \multicolumn{2}{|c|}{ Total } \\
\hline & & ind. & o & ind. & $\%$ & ind. & $\%$ & ind. & $\%$ & ind. & $\%$ & ind. & $\%$ & ind. & $\%$ & ind. & $\%$ \\
\hline $0+$ & 18 & 2658 & 94.6 & 32 & 1.14 & 77 & 2.74 & 14 & 0.5 & 17 & 0.6 & 13 & 0.46 & - & - & 2811 & 100 \\
\hline $1+$ & 32 & 4588 & 95.2 & 90 & 1.87 & 94 & 1.95 & 19 & 0.39 & 13 & 0.27 & 16 & 0.33 & - & - & 4821 & 100 \\
\hline $2+$ & 91 & 27583 & 96.0 & 612 & 2.13 & 192 & 0.67 & 149 & 0.52 & 35 & 0.12 & 136 & 0.47 & 4 & 0.01 & 28711 & 100 \\
\hline $3+$ & 19 & 6861 & 95.8 & 197 & 2.75 & 7 & 0.02 & 54 & 0.19 & 5 & 0.02 & 31 & 0.11 & 7 & 0.10 & 7161 & 100 \\
\hline $4+$ & 4 & & & & & & & & & & & 4 & 36.36 & 7 & 63.6 & 11 & 100 \\
\hline $5+$ & 2 & & & & & & & & & & & & & 2 & 100 & 2 & 100 \\
\hline
\end{tabular}


the Lake Miedwie individuals is compared to that of the Szczecin and Vistula Lagoons smelt, an opposite trend is found to take place, i.e., the Lake Miedwie smelt grow faster.

The growth rate of smelt studied was found to vary. Two groups of fishes, each showing a different growth rate, could have been identified in the material studied: juvenile individuals $(0+, 1+, 2+)$, usually showing their growth rate to be typical of a freshwater population that is a standard for Osmerus eperlanus, and older individuals, usually large and growing fast from the beginning. The two types of growth revealed for fish in the same water body indicate a presence of two separate populations in the material studied. Earlier studies by Rembiszewski (1970) who had found two populations of Osmerus eperlanus inhabiting the Lake Miedwie would support our finding. The author mentioned separated large Miedwie smelt into a distinct population of not only specific biological features but also some anatomical ones.

Smelt in Polish waters live up to 8 years. Most individuals in populations from various water bodies are found to belong to the second and third age groups (Rembiszewski, 1970). In the material studied, the oldest fishes belonged to the group 5+, this not being, however, a maximum age possible to attain in this lake. Rembiszewski (1970) and Cywiński (1974) found fishes at the age of 7 and even 8. It would appear that the Lake Miedwie smelt forms not only the largest but also the most long-lived population of the species in Poland.

In their first year of life, the Lake Miedwie smelt are typically plankton-feeders. Amount and type of food alter with aje older individuals more often rely on larger prey organisms, cannibalism being observed frequently in predatory smelt. That is a typical feeding behaviour of smelt, encountere also in representatives of the species in other water bodies (Wiktor, 1964; Belyanina, 1969).

Smelt is known for their predation on ablen and lavaret. Great losses are suffered by populations of those species as an effect of their aggs and juveniles falling prey to smelt (Korycki, 1966). No smelt predation on ablen and lavaret was, however, found in the Lake Miedwie as no eggs or juveniles were found in the digestive tracts examined. Moreover, the food competition between the three species cannot be excluded. To prove this would, however, call for a more detailed knowledge of food spectra of the Lake Miedwie ablen and lavaret. Owing to low abundances of the two species in the Lake and no possibilities to increase their stock because of a high eutrophication rate recorded for the Lake, a possible food competition between ablen, lavaret, and smelt, when found, would presumably be of no relevance.

\section{CONCLUSIONS}

1. Smclt is one of the most abundant components of the Lake Miedwie ichthyofauna. In spite of the fishes' small size, the contribution of the species to the total catch in the Lake is the highest. 
2. Small $(9-10 \mathrm{~cm})$ and young (2- and 3-year-old) individuals are most common in catches, older (up to 8 years) and larger $(28.0 \mathrm{~cm}$ ) ones being found as well.

3. The Lake Miedwie is inhabited by two populations of Osmerus eperlanus: one consisting of large Miedwie smelt and the other of standard freshwater smelt. The large Miedwie smelt showing a high rate of length and weight growth belong to Poland's fastest-growing smelt populations.

4. The Lake Miedwie smelt are typical plankton-feeders in their first years of life. Older individuals switch to predation including cannibalism.

5. Owing to favourable biological characters of the large Miedwie smelt population, efforts should be undertaken to introduce those fishes to other water bodies where, due to a change in environmental conditions, they can replace more vulnerable whitefish.

\section{References}

Almuchov K.A., Erostova V.M., 1974: Reproduction and ecology of early stages of development of smelts (Osmerus eperlanus L.) of the White Sea. - Vopr. Ichtiol. 16/6.

Belyanina T.N., 1969: Synopsis of biological data on smelt (Osmerus eperlanus L.) FAO Fish. Synop. 78.

Bernatowicz S., 1968: Znaczenie gospodarcze introdukcji i aklimatyzacji ryb. [Economic importance of introduction and acclimatisation of fish]. Oprac. brosz. [Manuscript]. IRŚ Olsztyn,

Cywiński S., 1974: Wzrost stynki (Osmerus eperlanus L.) z jez. Miedwie. [Growth of smelt (Osmerus eperlanus L.) in the Lake Miedwie]. AR Szczecin (mạszynopis) [Manuscript].

Fedorova G.V., 1973: Ulovy i biologičeskaja charakteristyka snetka czera Il'men. - Izvest. Gos. Nauč Issl. Inst. Oz. i Reč Ryb. Choz. 86, Leningrad.

Gąsowska M., 1962: Krągłouste i ryby [Cyclostomi et pisces]. PAN, Warszawa-Kraków.

Korycki A., 1953: Zagadnienia stynkowe na Pojezierzu Mazurskim. [On smelt in the Mazurian Lake District]. Gosp. ryb. 2.

Korycki A., 1966: Stynka. [Smelt]. Oprac. brosz. [Manuscript]. IRŚ, Olsztyn.

Koszutowski S., 1930: Przyczynek do znajomości stynki w Polsce. [A contribution to knowledge of smelt in Poland]. SGGW Warszawa (praca dyplomowa). [Manuscript].

Krzykawska I., 1970: Wzrost stynki (Osmerus eperlanus L.) z Zalewu Szczecińskiego. AR Szczecin (maszynopis) - [Growth of smelt (Osmerus eperlanus L.) in the Szczecin Firth]. [Manuscript].

Lillelund K., 1961: Untersuchungen über die Biologie und Populationsdynamik der Stintes der Elbe. - Archiv. für Fisch Wiss. 12-1.

Morduchaj-Boltovskoj F.D., 1954: Materialy po srednemu vesu vodnych bezpozvonočnych basena Dona. - Tr. Probl. i Tiemat. Soviešč. Vyp. II Izd. Ak. Nauk.

Murawska E., 1968: Odżywianie się młodocianej stynki (Osmerus eperıanus L.) w Zalewie Wiślanym. [Feeding of juvenile smelt (Osmerus eperlanus L.) in the Vistula Lagoon]. AR Szczecin (maszynopis). [Manuscript].

Rembiszewski J.M., 1970: Population variaton in smelt Osmerus eperlanus (L.) (Pisces in Poland). Ann. zool. PAN, 7.

Rybak J.I., 1971: Przewodnik do rozpoznania niektórych bezkręgowych zwierząt słodkowodnych. [A guide to identification of some freshwater invertebrates]. PAN, PWN-Warszawa. 
Starmach K., 1955: Metody badania planktonu. [ Methods of studying plankton]. PWRiL Warszawa. Szydłowski M., Dębska M., Kaczmarek W., Kudyńska J., Olechowicz A., 1974: Teoria pomiarów. [Theory of measurements]. PWN Warszawa.

Wiktor K., 1964: Związki między produkcją zooplanktonu a odży wianiem się ryb planktonożernych. [Relations between zooplankton production and feeding of fish plankton-feeders]. Studia i Materiały, ser. A, MIR Gdynia.

\section{WZROST, ODZ̊YWIANIE SIĘ I ZNACZENIE GOSPODARCZE STYNKI (OSMERUS EPERLANUS L.) Z JEZIORA MIEDWIE}

\section{Streszczenie}

W pracy umówiono wzrost, odżywianie się i znaczenie gospodarcze stynki (Osmerus eperlanus L.) z jeziora Miedwic. Materiał do badań w liczbie 503 szt. ryb, zebrano w latach 1976-1977. Wzrost stynki oznaczano na podstawie odczytów wstecznych z otolitów bez stosowania poprawek. Badania w zakresic odżywiania się stynki dotyczyły składu ilościowego i jakościowego pokarmu oraz częstości występowania jego składników.

$Z$ danych połowowych wynika, że stynka należy do najliczniejszych gatunków ichtiofauny jeziora Miedwie. W ostatnich Jatach połowy stynki wyraźnie wzrosły. W pobranych próbach najwięcej ryb przypadało na klasy długości: 10,$0 ; 10,5 ; 9,5 \mathrm{~cm}$, które stanowiły $58,4 \%$ materiału. Pod względem wicku dominowały osobniki młode $0^{+} 1^{+} \mathrm{i} 2^{+}$stanowiące $89,2 \%$ badanych ryb.

Tempo wzrostu stynki jeziora Miedwic w zależności od wieku ryb jest zróżnicowane. Osobniki młodsze $\left(0^{+}-2^{+}\right)$odznaczają się niewielkimi rozmiarami i wolnym tempem wzrostu, natomiast starsze rosną szybciej. Odmienne tempo wzrostu różnych osobników stynki spowodowane jest przypuszczalnie przynależnością do dwóch różnych populacji: śródlądowej - wolno rosnącej i miedwiańskiej szybko rosnącej.

W pierwszych latach życia stynka z jeziora Miedwie jest typowym planktonofagiem. Głównym składnikiem jej pokarmu w okresie zimowo-wiosennym są Copepoda. W wieku $2^{+}$staje się stopniowo drapieżnikiem odżywiając się rybami (głównie młodzieżą stynki), które w następnych latach stają się jej jedynym pokarmem.

Populację dużej stynki miedwiańskiej, ze względu na korzystnc jej cechy biologiczne, powinno się wprowadzać do innych jezior, szczególnie tycl, które stały się już nieodpowiednie dla sielawy.

Р. Тщебятовски, Й. Гай

\section{PОСТ, ПИТАНИЕ И. ХОЗЯЙСТВЕННОЕ ЗНАЧЕНИЕ КОРЮШКИ (OSMERUS EPERLANUS I.) ИЗ O3EPA MEДBE \\ $P$ e 3 ○}

В работе рассматривается рост, питание и хозяйственное значение корюшки (osmerus eperlanus ј॰) из оз. Медве. Материалл для исследований (503 экз. корюшки) был собран в 1976-1977 гг. Рост корюшки определяли на основе обратных вычислений по отолитам без применения поправок. Исследования в области питания корюшки касались количественного и качественного состава корма, а также частоты встречаемости его компонентов. 
Пз промысловых данных следует, что корюшка принадлежит к самым многочисленным видам ихтиофауны озера Медве. В последние годы вылов корюшки резко увеличился. Во взятых пробах наибольшее количество рыбы приходилось на следующи размерные группы: 10,$0 ; 10,5 ; 9,5$ см, что составляет 58,4\% от всего материала. С точки зрения возраста преобладали молодые особи $0^{+}, 1^{+}$ и $2^{+}$, составляющие $89,2 \%$ от всей исследуемой рыбы。

Темп роста корюшки из оз. Медве в зависимости от возраста рыб является разным. Более молодые особи $\left(\mathrm{O}^{+}-2^{+}\right)$характеризуются небольшими размерами и медленным темпом роста, более взрослые же растут быстрее. Различный темп роста разных особей корюшки вызван очевидно принадлежностью к двум разным популяциям: внутриконтинентальной, растущей медленно, и местной, растущей более быстро.

В первые годы жизни корюшка из оз. Медве является типичным планктонофагом. Основным компонентом её корма в зимне-весенний период являются копеподы. В возросте $2^{+}$корюшка постепенно становится хищинком и питается рыбой (в основном собственной молодью), которая в последующие годы становится единственным её кормом .

Попу ляцию крупной местной (медвинской) корюшки с точки зрения её полезных биологических признаков следует впускать в другие озёра, особеннов те, которые стали уже непригодными для ряпушки.

Address:

Doc. dr Rajmund Trzebiatowski

Insty tut Akwakultury i Techniki Rybackiej AR

71-550 Szczecin, ul. Kazimierza Królewicza 4

Polska-Poland 